\title{
TRAINING MANAGEMENT MODEL FOR HUMAN RESOURCE CAPACITY BUILDING (ANALYSIS OF EDUCATION AND TRAINING AGENCY, WEST JAVA PROVINCE, INDONESIA)
}

\author{
Mustakim \\ Researcher, Indonesia University of Education, Indonesia, mustakimpls@student.upi.edu
}

\begin{abstract}
Stakeholder is a driving force in an organization. However, over time, an organization cannot be avoided with the crisis of leadership. This condition is due to the lack of human resources that has credibility and capacity as a leader. Through the Training Management Model, it aims to improve the capacity of human resources, which is expected to become a model of the emergence of future leaders. The civil service is a state apparatus that works to serve the State of the Republic of Indonesia. Then, a civil servant will occupy positions within the institution, He/she must have a minimum rank of echelon IV. The purpose of this study is to obtain training management model that can improve employee performance, and increase the capacity of human resources. This study employed mixed methods, quantitative and qualitative approaches. Furthermore, in collecting the data collection, the author performed interviews, documentation, observations and questionnaires. The results of this study were elaborated briefly as follows: (1) Training management model among others by applying a training needs analysis (TNA), employee goals, training infrastructure, training design, program structure, and training budget plan. (2) The capacity of human resources includes an increase in knowledge, motivation, leadership, job performance, attitude in work and additional duties (the working visit). (3) The impact of training on performance management of human resources is that: the employees have the skills to be a leader of an institution, high motivation in work, and responsibility in carrying out their duties. Based on the correlation coefficient between management training with employee performance could be concluded that there was significant influence. Based on the findings of the obtained data, it showed coefficients amounting to 0.846 or $84.6 \%$. Therefore, it was proven that the influence between two variables was very strong in the range coefficient from 0.80 to 1.000 .
\end{abstract}

Keywords: Training Management Model, Human Resource Capacity and Employee Performance.

\section{INTRODUCTION}

Leader is considered as the forefront of an organization. Leader is responsible for the progress and the deterioration of an institution. In many cases, it can be easily found that a leader has a lack of confidence. This condition will probably take place due to the lacks of leaderships, human resources, and responsibilities. Since the development of an organization is mainly depended on its controller, the role of a leader within an organization is viewed as a vital element. "The role of a leader, in fact, determines the change and 
continuation of a company" (Ancok, 2012).

According to Government Regulation No. 13 Year 2002 concerning structural position, a leader of an institution is defined as a position that indicates the duties, responsibilities, authority, and the rights of civil servants to lead a government agency (Peraturan Pemerintah No 13, 2002). As a civil servant who occupy certain positions in government institutions, qualified by education level is a must to have. In an effort to produce a quality leader, the qualifications as mentioned previously is then necessary to initiate special education and training. This is in line with the national education system that the training was organized to review those who need a stock of knowledge, skills, life skills, attitudes to develop themselves, to develop the profession, employment, independent business, and / or continue their education to a higher level (Sisdiknas, 2003)

In order to improve the performance and responsibility of the candidates of institutional leaders, Education and Training Agency, West Java Province in collaboration with Regional Employee Affairs initiate to organize a Leadership Training. In addition, this Leadership Training aims at establishing operational leadership competencies and preparing future leaders in government institutions. The participants of the training came from the civil servants echelon IV class. "... The structural officials echelon IV plays a crucial role in planning the implementation of the institutional activities and leading the employees as well as strategic stakeholders to implement the agreed activities effectively and efficiently (Pedoman Penyelenggaraan Pendidikan dan Pelatihan Kepemimpinan Tingkat IV, 2013).

One of the requirements that should be mastered by Echelon IV is that they are encouraged to have an operational leadership. This compulsory criterion is considered as a strategic leadership. In particular, since it, not only, functions to control human resources, as well as controller activity, it also plans the design activities to develop and promote the units of work.

\section{RESEARCH PURPOSES}

In general, the aim of the training management model in the context of human resource development includes: obtaining a training management model that can improve employee performance, the capacity of human resources in the related institutions or agencies, and knowledge, motivation, performance, and leadership in actuating the responsibilities within an institution.

In particular, this study has formulated several research purposes which cover:

a. To analyze the training management models organized by the Education and Training Agency, West Java Province.

b. To describe the capacity of human resources in Education and Training Agency, West Java Province.

c. To analyze the impacts of the training management on the performance of human resources in Education and Training Agency, West Java Province.

\section{METHODOLOGY}

This study employed a mixed method, quantitative and qualitative approaches. Visually, it is also called as a Explanatory sequential design (Creswell, 2015) as seen in figure 3.1 as follows:

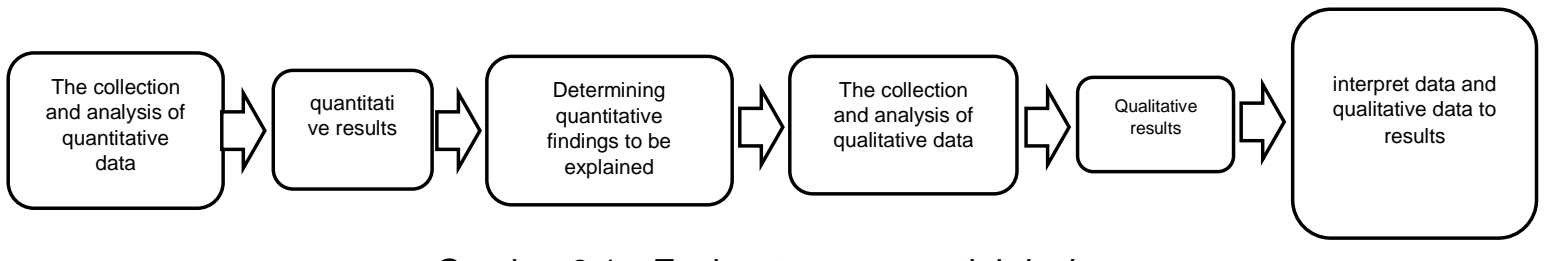

Gambar 3.1: Explanatory sequential design

In this present study, there were two types of collecting data covering questionnaire and interview. In the first phase of collecting data, the questionnaire is distributed and circulated to the five respondents. Then, in the next phase, the data were taken form an interview session with one manager, observation and documentation. As all phases of data collection completed, the obtained data were then analyzed quantitatively and qualitatively. Specifically, in the process of analyzing the data quantitatively, there were several statistical measures based on variables that were performed covering research normality test, linear regression analysis, simple correlation analysis, significance test, and test the coefficient of determination. On the other hand, based on the qualitative approach, there were also some analytical phases that included 
data reduction, data display, and conclusion drawing / verifying.

\section{RESULTS AND DISCUSSION}

Based on the results of the study, consisting of a series of phases such as interviews, observations, documentations, and questionnaires carried out continuously, the findings will be in detail elaborated as below:

\subsection{Training Management Model Organized by Education and Training Agency, West Java Province}

Training Management Model on leadership training begins with an analysis of the needs of the institution. The analysis of institutional needs consist of the employee qualification and performance. The qualification of an employee in Education and Training Agency in West Java province is determined by the Ministry of Home Affairs. On the other hand, as for employees who attended the training leadership training, Training Management Model using the analysis of training needs and training priorities, the priority training is a step that is used to measure the actual and ideal performance. Through the training priorities, there is a gap between the conditions of real and expected performance. Therefore, the analysis of training needs is assumed to be needed in order to determine the training priorities. Employee performance can be measured by employee performance goals. Employee performance goal is a monthly report of an employee who refers to the three aspects: 1) employee performances, 2) employee attitudes, and 3) additional duties.

In order to support the performance of employees in Education and Training Agency, the participants of the leadership training are equipped with some supporting facilities during the training, such as classrooms, LCD, loudspeaker, white board, stationary, tables, chairs and other needed facilities. In addition, the infrastructures that supported the event included: the training building, worship facilities, boarding facilities, fitness facilities, sports fields, parking lots and other needed facilities.

The design of the training leadership in Educational and Training Agency in West Java Province has several steps as follows: general and specific objectives, course structure, teaching materials, training participants, speakers / facilitators, training strategies, instructional media, infrastructure, costs and training evaluation.

On the design of the leadership training, it has a common objective in order to establish operational leadership competencies towards echelon IV officials, and act as well as carry out the duties and functions of the leadership in their respective institution. On the other hand, the specific purpose was formulated in order to build a character and attitude, behavioral integrity, to plan the implementation of the agency's activities, to collaborate internally and externally, to initiate innovations, to optimize all potential of the internal and external resources.

Then, the structure of the program on leadership training consisted of of three structures covering (1) the structure of training material, (2) classification of the theory, and (3) the number of courses. Training material structure refers to the instructions of the State Administration Institution (LAN). Classification of training was elaborated to have $70 \%$ of theory and $30 \%$ of practice. Finally, the number of training courses would take for 36 days which are elaborated in detail as 1 hour course for 45 minutes, starting at 8:00 to 17:00 pm and carried out generally around 893 hours of courses.

Based on the standard competencies, the leadership training instructional materials are formulated as follows: (1) management of learning, (2) personal competence, (3) social competence, (4) substantive competence. Firstly, the learning management of sub-competencies is arranged as follows: making the lesson plan, preparing teaching material, applying the adult learning methods, communicating effectively with the participants, motivating the participants, and evaluating the learning processes. Secondly, sub personal competence includes: displaying personality that can be emulated and modeled, implementing a code of ethics and demonstrated work ethic and provisional widyaswara. Social competence sub competencies covers several aspects as follows: maintaining good relationship and cooperation with fellow widyaswara, and a relationship with the organizer / manager of the training institution. Competence substantive sub competencies covers several aspects as follows: mastering the knowledge and skills to practice as in accordance with the explained training material, and writing scientific writing related to the scope of the development of specialization.

In the recruitment process, the participants were selected by the Regional Personnel Agency (BKD). In this event, the chosen speakers were also taken based on the qualifications, such as having master degree, having competencies for training materials, and having a certificate of training of trainers (TOT). Training strategies used for the training were the learning strategies of andragogy, through lectures, discussion, brainstorming, leadership simulations. During the implementation of the training, the classrooms in the 
second and third floor in the building of Education and Training Agency of West Java Province were used as the training location.

The costs of the implementation of this training were taken from the State Budget (APBN) of West Java province in 2016, Rp. 111215998 000, - (one hundred eleven trillion two hundred and fifteen million nine hundred and ninety-eight thousand rupiah). While the evaluation of training participant evaluation, evaluation of the final results of the graduation, evaluation of widyaswara / speakers, evaluation of organizers, and posttraining evaluation.

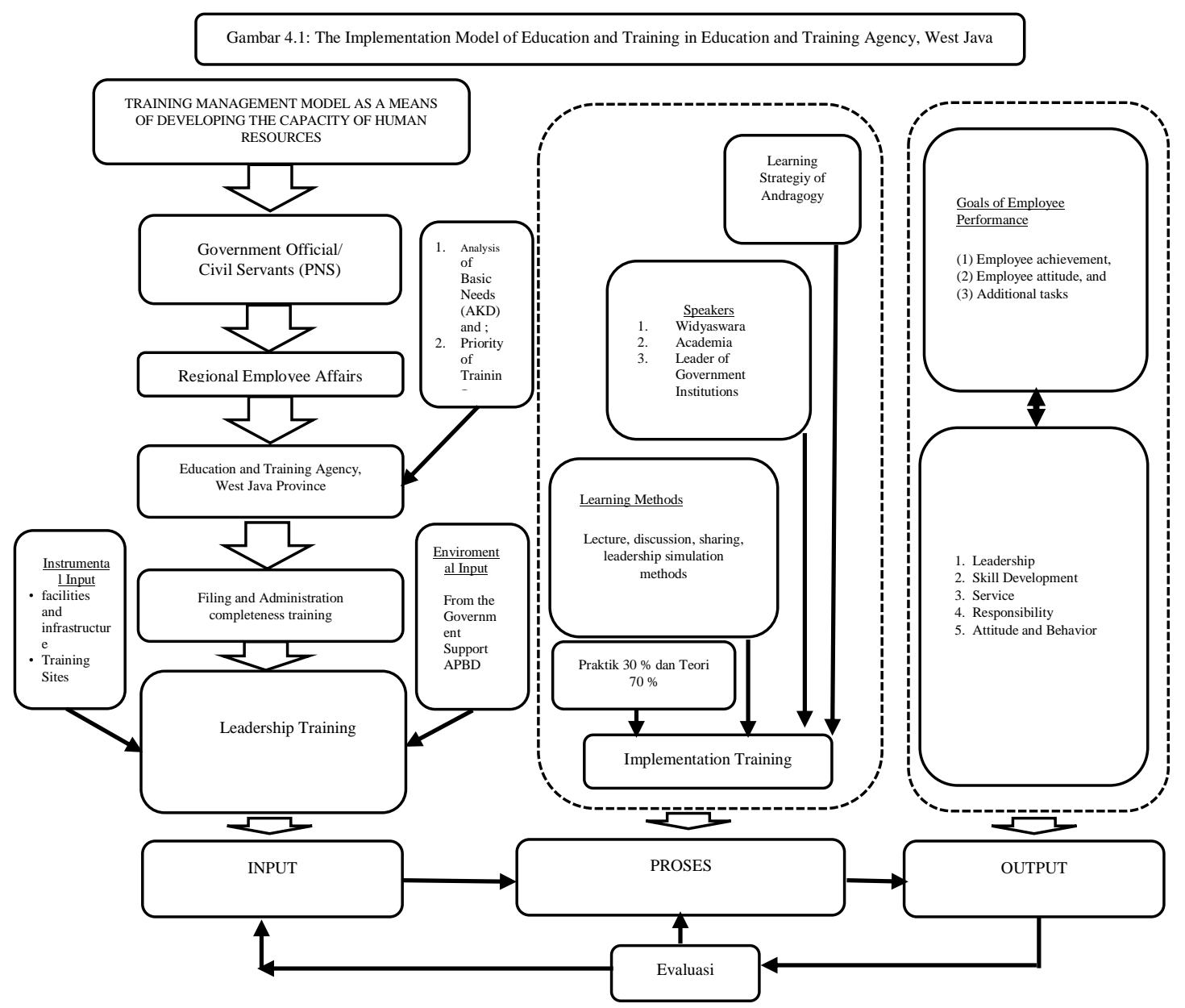

\subsection{The Capacity of Human Resources in Education and Training Agency in West Java Province}

The capacity of excellent human resources is assumed to be more valuable for an institution. However, excellent human resources must be improved continuously. One of the improvements of human resources can be achieved through consistent and continuous trainings. In Education and Training Agency of West Java Province, the capacity of human resources is determined based on the levels of knowledge, skills, and attitudes and ethics of the training participants.

The capacity of human resources in the context of the knowledge levels of the participants is viewed from several aspects, such as: the professions, procurement of duties, and the factors supporting the procurement of the duties. Based on the professions, the majority of the participants were taken from the areas of administration, with a good mastery of the task. While the factors that support the task mastery of the participants consist of: an educational background which is not in accordance with the profession, lack of skills and understandings in the context of technology. Therefore, it is necessary to enhance the sustainable human resources.

The capacity of human resources in the context of the skills of the involved participants consisted of: program planning, task completion, procurement of facilities and technology. Specifically, planning program of the participants in doing the tasks used the listing plan in advance. The completion of the duties that were 
assigned was set to the target, but still prioritized to the important parts of job. In the point of the mastery of the facilities within workroom, the majority of participants have not been able to master the provided technology. Instead, the role of technology was considered vital in supporting their performance.

The capacity of human resources in context of attitudes and ethics of the training participants consisted of: independence, honesty, obedience, discipline, and cooperation. In particular, due to the numerous tasks in team, independence of the participants in doing the tasks was assumed to be very small as the consequence. Secondly, the honesty was in accordance with the duties and functions of the job. Thirdly, the obedience of training participants to the applicable work ethics in the workplace was for 7 hours of work in a day. The discipline of the training participants when they came at the workplace was in accordance with a predetermined time. The cooperation in terms of completing the task is executed in groups.

\subsection{The Impacts of Training Management on Human Resource Performance in Education and Training Agency, West Java Province}

The impacts of the training management on the performance of human resources can be viewed from several aspects such as: expertise, encouragement, service, and responsibility. Expertise in this case is the expertise of each participant. The skills or competencies possessed by the participants can be viewed in the contexts of operating computer well, communicating in a good way, being encouraged to learn new things, and having experiences in leadership. It is also important to have a motivation to be an initiative leader, enthusiasm in work, and proud of the job from the boss. In addition, it is also important to provide a maximum service in work as well as have a responsibility in the task as a candidate of future leader of an organization.

The impact of training management on performance of human resources in Education and Training Agency in West Java province can be hypothesized as follows:

$\mathrm{Ha}$ : The results of the training have a positive and significant effect on the performance of employees in the Education and Training Agency in West Java Province.

Ho: The results of the training do not have a positive and significant effect on the performance of employees in the Education and Training Agency in West Java Province.

In order to study the aforesaid hypothesis, it is needed to use parametric statistical calculations due to normal data distribution. Furthermore, the calculation process of the data uses SPSS statistics 22 for Windows and Microsoft Office Exel 2013. The results of data analysis can be obtained by following the steps below.

\subsubsection{Normality Test (Data Distribution)}

Tabel 4.3.1 Descriptive Statistics

\begin{tabular}{|c|c|c|c|}
\hline & & Training & Performance \\
\hline \multirow{2}{*}{$N$} & Valid & 5 & 5 \\
\hline & Missing & 0 & 0 \\
\hline \multicolumn{2}{|c|}{ Mean } & 61.6000 & 60.4000 \\
\hline \multicolumn{2}{|c|}{ Median } & 62.0000 & 62.0000 \\
\hline \multicolumn{2}{|c|}{ Std. Deviation } & 9.65919 & 5.85662 \\
\hline \multicolumn{2}{|c|}{ Minimum } & 49.00 & 52.00 \\
\hline \multicolumn{2}{|c|}{ Maximum } & 74.00 & 66.00 \\
\hline \multicolumn{2}{|c|}{ Sum } & 308.00 & 302.00 \\
\hline
\end{tabular}

According to the results presented in Table 4.3.1, It informed that that that the average scores and standard 
deviation for each variable showed that the highest scores for the variable $(X)$ Training had the highest score around 74 and the lowest ones around 49 with the mean 61.6, median 62, std. Deviation 9.65919 and Sum 308. On the other hand, the variable ( $Y$ ) Performance had a highest score around 66 and the lowest ones around 52, with the mean 60.4, 62 media, std. Deviation 5.85662 and Sum 302.

\subsubsection{Normality Test for Variable $X$ (Training Management) and $Y$ (Performance)}

Table 4.3.2 Normality Test

\begin{tabular}{|l|c|c|c|c|c|c|}
\hline \multirow{2}{*}{} & \multicolumn{3}{|c|}{ Kolmogorov-Smirnov $^{\mathrm{a}}$} & \multicolumn{3}{c|}{ Shapiro-Wilk } \\
\cline { 2 - 7 } & Statistic & $\mathrm{df}$ & Sig. & Statistic & $\mathrm{df}$ & Sig. \\
\hline Training & .119 & 5 & $.200^{*}$ & .995 & 5 & .994 \\
Performance & .208 & 5 & $.200^{*}$ & .920 & 5 & .531 \\
\hline
\end{tabular}

*. This is a lower bound of the true significance.

a. Lilliefors Significance Correction

The significance of research results for the variable $X$ (Training) could be identified around $0.200>0.05$, and for the variable $Y$ (Performance) around $0.200>0.05$. Based on these facts, it could be assumed that the data was distributed normally.

\subsubsection{Simple and Double Linier Regression Analysis}

Simple linear regression analysis was employed to predict the extent to which the value of the variable $Y$ (Employee Performance) was influenced by the value of the variant in the variable X (Training Results).

$$
\hat{Y}=a+b X
$$

The first of this analysis was to find the value $a$ and $b$. The following table on the calculation results of the value $a$ and $b$ using SPSS statistics 22 for Windows and Microsoft Office Exel 2013 were as follows:

Table 4.3.3 Coefficients ${ }^{\mathrm{a}}$

\begin{tabular}{|c|c|c|c|c|c|c|}
\hline \multirow{2}{*}{\multicolumn{2}{|c|}{ Model }} & \multicolumn{2}{|c|}{$\begin{array}{c}\text { Unstandardized } \\
\text { Coefficients }\end{array}$} & \multirow{2}{*}{\begin{tabular}{|c} 
Standardized \\
Coefficients \\
Beta \\
\end{tabular}} & \multirow[b]{2}{*}{$\mathrm{t}$} & \multirow[b]{2}{*}{ Sig. } \\
\hline & & $\mathrm{B}$ & Std. Error & & & \\
\hline 1 & (Constant) & 25.275 & 7.404 & & 3.414 & .042 \\
\hline & Training & .570 & .119 & .940 & 4.791 & .017 \\
\hline
\end{tabular}

a. Dependent Variable: Kinerja

Based on the calculation results of the above table, it was known that the value a a (constant) was 25.275 and the value $b$ (beta) was 0.570 . Hence, based on the aforementioned results, it could be formulated the regression model as follow.

$\hat{\mathrm{Y}}=25.275+0.570 X$

The constanta value a indicated that when the variable Training $(\mathrm{X})$ was 0 or Employee Performance $(\mathrm{Y})$ was not affected by the training, the average of employees performance was 25275 . On the other side, the regression of coefficient $b$ indicated that if the variable Training $(X)$ was increased by the unit, then the employee performance would increase significantly around 0570 .

\subsubsection{Variant Analysis in Regression (ANOVA)}

Testing the effect of variable $X$ (Training) towards variable $Y$ (Employee Performance) as stated in the regression equation, was carried out through the analysis of variance in a regression analysis of the data variable $X$ (Training) and $Y$ (Employee Performance). The first criteria was to reject zero hypothesis that stated the coefficient of direction regression was accepted if $F$ count> $F$ table. The second criterion was to reject the null hypothesis that stated the regression was linear if $F$ count $<F$ table. Therefore, the condition of 
this hypothesis was accepted.

Table 4.3.4 ANOVA $^{a}$

\begin{tabular}{|c|c|c|c|c|c|c|}
\hline \multicolumn{2}{|c|}{ Model } & $\begin{array}{l}\text { Sum of } \\
\text { Squares }\end{array}$ & Df & Mean Square & $\mathrm{F}$ & Sig. \\
\hline \multirow[t]{3}{*}{1} & Regression & 121.339 & 1 & 121.339 & 22.951 & $.017^{b}$ \\
\hline & Residual & 15.861 & 3 & 5.287 & & \\
\hline & Total & 137.200 & 4 & & & \\
\hline
\end{tabular}

a. Dependent Variable: Kinerja

b. Predictors: (Constant), Pelatihan

Testing criterion was that $Y$ was independent (not dependent) on $X$ if $F$ count $<F$ table, but it was dependent (dependent) when it was vice versa. Based on the results of the table above, ANOVA calculations was obtained $\mathrm{F}$ count $>\mathrm{F}$ table or $22.95>10.13$. These results indicated that employee performance of variable $(Y)$ depended on the results of the training $(X)$, it also meant that the training results $(X)$ depended on the employee performance $(\mathrm{Y})$.

\subsubsection{Coefficient Correlation Analysis}

Based on the results of the normality test of data distribution, it was clear that the data from both variable $X$ (training) and variable $Y$ (employee performance) were in normal distribution. Therefore, the appropriate statistics used to analyze the coefficient correlation was a parametric statistics.

Table 4.3.5 Correlations

\begin{tabular}{|lc|c|c|}
\hline & & Training & Performance \\
\hline Training & Pearson Correlation & 1 & $.940^{*}$ \\
& Sig. (2-tailed) & & .017 \\
& $\mathrm{~N}$ & 5 & 5 \\
\hline Performan & Pearson Correlation & $.940^{*}$ & 1 \\
ce & Sig. (2-tailed) & .017 & \\
& $\mathrm{~N}$ & 5 & 5 \\
\hline
\end{tabular}

*. Correlation is significant at the 0.05 level (2-tailed).

Based on the table above, it was obvious that the magnitude of variable correlation $X$ towards variable $Y$ was 0.940. Then, the results of the calculation above were related to the table of correlation interpretation as stated by (Sugiyono, 2012) as follow:

Table 4.3.5a

Guidance of Coefficient Correlation Interpretation

\begin{tabular}{|c|c|}
\hline Coefficient Values & Levels of Relation \\
\hline $0,00-0,199$ & Very Low \\
\hline $0,20-0,399$ & Low \\
\hline $0,40-0,599$ & Medium \\
\hline $0,60-0,7999$ & Strong \\
\hline $0,80-1,000$ & Very Strong \\
\hline
\end{tabular}

By looking at the benchmark tables have been determined, then the correlation coefficient between the variables of training results with the performance of employees belong to a classification of Very Strong 
correlation. Thus, there is a relationship that is relevant to a positive direction between the results of training with employee performance.

\subsubsection{Correlation Significance Test}

After completing the calculation applied to know Coefficient Correlation, it was necessary to do the calculation of correlation significance test between variables $\mathrm{X}$ and $\mathrm{Y}$. This test was indicated in table 4.3.5 (correlations). The research hypothesis that would be tested and formulated could be seen as below:

$$
\begin{aligned}
& \text { Ho: } r_{y x}=0 \\
& \text { Ha: } r_{y x} \neq 0
\end{aligned}
$$

\section{Decision-making:}

If the probability 0.05 is less than or equal to the probability Sig or (Sig $\leq 0.05)$, then Ho is accepted and $\mathrm{Ha}$ is rejected, it means insignificant.

If the probability 0.05 is less than or equal to the probability Sig or ( $\geq 0.05 \mathrm{Sig}$ ), then Ho is rejected da $\mathrm{Ha}$ accepted, it means significant.

Based on Table 4.5. Table of Correlations, the variable as the results of the training and employee performance yielded the significant probability value around 0017 . As the value of significance obtained, it was then compared to the probability value 0.05 . It has been known that the probability value 0.05 was assumed to be greater than the probability value of significance or $(0.05>0.017)$. Then, Ho was rejected and $\mathrm{Ha}$ was accepted. This result indicated that the Training had a positive and significant impact on employee performance.

\subsubsection{Determination Coefficient Test}

Determination coefficient test was employed with the purpose of determining the contribution of variable $X$ (Training) towards the variable Y (Employee Performance).

The results of the calculation of table $r^{2}$ (R Square) using SPSS statistics 22 for Windows could be seen as elaborated as follows:

$\begin{aligned} K D & =r^{2} \times 100 \% \\ & =0,846 \times 100 \% \\ & =84,6 \%\end{aligned}$

Then, in order to know the contribution of variable $X$ (Training Results) towards variable $Y$ (Employee Performance), it could be identified using the formula postulated by (Akdon, 2005) as seen below:

Table 4.3.7 Model Summary

\begin{tabular}{|c|c|c|c|c|}
\hline Model & $\mathrm{R}$ & R Square & $\begin{array}{c}\text { Adjusted R } \\
\text { Square }\end{array}$ & $\begin{array}{c}\text { Std. Error of the } \\
\text { Estimate }\end{array}$ \\
\hline 1 & $.940 \mathrm{a}$ & .884 & .846 & 2.29932 \\
\hline
\end{tabular}

a. Predictors: (Constant), Pelatihan

Based on the calculation above, it was clear that the value $84,6 \%$, meant that the variable as the results of the training made a contribution around $84,6 \%$ towards employee performance and the rest of them around $15,4 \%$ was influenced by other variables.

\section{CONCLUSIONS}

Training Management Model as an attempt to improve the capacity of human resources in Education and Training Agency, West Java province, can be in detail elaborated as follows: 


\subsection{Training Management Model Organized by Education and Training Agency, West Java Province}

In general, the training management model organized by Educational and Training Agency in West Java Province has implemented the analysis of training needs, starting from the analysis of the institution's needs, analysis of the characteristics and learning needs, as well as the analysis of training devices. In an attempt to determine the qualification of participants of the training, the employees in Education and Training Agency, West Java Province through the analysis training needs (AKD) in cooperation with the Regional Employee Agency (BKD) are assigned to recruit training participants. The results of the recruitment are given to Education and Training Agency to be selected based on the needs of the training participants.

In order to observe the needs of the training participants through Training Needs Assessment (TNA), the manager of the training program formulate the purpose of training, structure of training, to-be-given teaching materials, speakers, learning strategies, facilities and infrastructures used during the event, funds of the training and evaluation of training.

However, the management procedures of Education and Training Agency, West Java Province still apply training program plans, organizations, implementation and evaluation of the training carried out as programmed. In a bottom line, this program is expected to be implemented successfully as it has been programmed in advance.

\subsection{The Capacity of Human Resource in Education and Training Agency, West Java Province}

After attending the training, the capacity of human resources in education and Training Agency, West Java province has undergone a significant change and development. In fact, it can be seen that the participants have shown a significant progress of the performance in the office and an increase in terms of knowledge from which their understanding regarding their responsibilities in workplace have been gradually improved and as a result, they can complete the tasks professionally. In addition, the improvement of skills in mastering technology can also be seen from the shifting the flow of working. The manual systems have been modified into computer-based systems.

Furthermore, the participants of the training have understood generally on the goals of employee (SKP) in which the employees at least know and implement the three aspects: (1) achievement of employees, (2) attitude of employees, and (3) additional tasks. Therefore, these three aspects will be assessed every month, so that the employees will abide the code of ethics and rules in the institution. Moreover, through these three aspects, the level of delays can be minimized every day. Therefore, the culture of discipline in workplace can be achieved as a reflection of the attitudes and ethics of civil servants in the environment of Education and Training Agency, West Java Province.

\subsection{The Impacts of Training Management on Human Resource Performance in Education and Training Agency, West Java Province}

The impact of the training management on the performance of human resources (training participants) in Education and Training Agency in West Java Province cannot be avoided. The participants of the training have shown an improvement after attending the training. It can be proven that formerly, the participants whose jobs are not in the same field can adapt with the current job. In fact, the participants of the training have had the attitude and behavior of loyalty and obedience to the State, good moral and mental, professionality, awareness of the responsibility as a public servant, as well as a unifier of national unity.

The significant influence between the effects of management training and human resources performance can be seen from the findings of the data analysis using SPSS by resulting in the coefficient of 0.846 , or $84.6 \%$. Based on this clear number, it can be interpreted that the influence of these two variables is assumed to be very strong.

\section{ACKNOWLEDGMENT}

The author would like to thank Indonesia Endowment Fund for Education (LPDP) Scholarship, Ministry of Finance of the Republic of Indonesia that has supported this research. 


\section{REFERENCE LIST}

Akdon, dan H. S. (2005). Aplikasi Statistik dan Metode Penelitian Untuk Administrasi dan Manajemen. Bandung: Dewa Ruchi.

Ancok, D. (2012). Psikologi Kepemimpina \& Inovasi. (R. Rahmat \& H. Retnowulan, Eds.). Jakarta: Erlangga.

Pedoman Penyelenggaraan Pendidikan dan Pelatihan Kepemimpinan Tingkat IV (2013). Jakarta, Indonesia.

Peraturan Pemerintah No 13. (2002). Pengangkatan Pegawai Negeri Sipil Dalam Jabatan Struktural,. Jakarta.

Sisdiknas. Sistem Pendidikan Nasional (2003). Jakarta.

Sugiyono. (2012). Metode Penelitian Kualitatif Kuantitatif dan R\&D (17th ed.). Bandung: Alfabeta. 